\title{
Exploring Parental Involvement in Education in Selected Inclusive Secondary Schools in Maseru District, Lesotho
}

\author{
Malehlanye Constantinus Ralejoe ${ }^{1}$ \\ ${ }^{1}$ Schools' Management Advisor, Bocheletsane Combined School, Ministry of Education and Training, Lesotho \\ Correspondence: Malehlanye Constantinus Ralejoe, Schools' Management Advisor, Bocheletsane Combined \\ School, Ministry of Education and Training, Lesotho.
}

Received: March 24, 2021; Accepted: April 5, 2021; Published: April 27, 2021

\begin{abstract}
This study investigated parental understanding of the concept "Parental Involvement in Education" of their children (PIE) in three inclusive secondary schools in the Maseru District of Lesotho. It also investigated the extent to which parents make contributions to the education of their children. The study was quantitative, exploratory in nature and used a 5-point Likert scale questionnaire to collect data. 700 parents in these schools were randomly selected to fill the questionnaires and the data were analysed using Statistical Package for the Social Sciences (SPSS) software. The results revealed that most parents understand PIE and its implications, but do not do much to assist teachers in schools. Mothers appeared to support the teaching of their children more than fathers. Prominent barriers in their efforts to help teachers included work-related commitments and a lower level of education. The study proposed formation of support groups involving all stakeholders for the purpose of raising awareness about PIE, educating parents about their roles in the education of their children, and improving communication among all stakeholders.
\end{abstract}

Keywords: education, learners, parents, teachers

\section{Introduction}

Inclusive education cannot survive without direct involvement of external agencies, such as parents. Parents are considered to be the most valuable partners in education. Macfarlane (2005) stresses that parental skills and knowledge can be utilised to support schools' activities. According to Macfarlane, parents are key in terms of supplying the schools with information concerning their children. In other words, parents know their children better than anyone else, and so they can provide information about how their children (more significantly those with disabilities and/or special educational needs) function in various settings.

In Lesotho, a parent is not just a biological father or mother of a child, but every adult. Traditionally, Basotho have youth gathering centres in villages, and these are called Thakaneng. In the evenings, teenagers and youth assemble at Thakaneng so that they can be taught about Basotho folklore and traditional plays. The elderly (mostly women) are responsible for the evening teachings, and they alternately teach individually or in teams. As they reach adolescence, Basotho children are expected to attend an initiation school in order to be circumcised and to receive training on skills such as sewing for shields and clothing, agriculture, hunting, respect, patriotism and livestock farming - if they are boys. It is at this stage that adult males are actively involved. The female adolescents have their separate initiation school, where initiated females teach them about womanhood (e.g. resilience strategies in respect of family challenges), sex-related issues, behaviour towards men, respect, and domestic and agricultural activities (Lesitsi, 1990). Although specific adults are entrusted with full-time nurturing of the initiates, it is equally the responsibility of every initiated adult to regularly visit the initiates in order to impart individual skills and expertise. However, it is not clear how children with disabilities were included (if ever they were) in Basotho traditional schooling. The introduction of modern schooling by the Christian missionaries in around 1833 (Paris Missionary Society) and 1862 (French Oblate Missionaries), resulted in traditional education losing value within Basotho society.

Probably influenced by the history of extended family structure, and the African collective or corporate responsibility, where every adult is directly responsible for the well-being, welfare, care and proper nurturing of children within the community, the Lesotho Education Act, 2010 defines a parent as:

[A person] who in law or by virtue of an order of a competent court has the custody or control of a learner, or a legal guardian, or in the absence of such parent or legal guardian, the person with whom 
the learner resides and to whom the parent or guardian has entrusted, in writing, the custody or control of such learner, or if the learner has no parent or legal guardian, the person with whom the learner resides and who has the actual custody or control of such learner.

In Lesotho, parental involvement in (secondary) education (PIE) is mainly in school-level decision-making through statutory school management councils called school boards. Each school board consists of nine members (two members nominated by a proprietor, three members nominated by parents, the teachers' representative, local chief or his/her representative, a member of local council, and the principal of the school). These boards have limited discretionary powers over major educational aspects such as curriculum development - as most control is centralised. According to the Education Act, 2010, parents should have a meeting with their representatives on the school board at least twice a year and the reports of such meetings should be provided to the school board. The chairperson of the school board is mandated to ensure that such meetings take place. It was hoped that these meetings would strongly liaise parents with schools. However, the researcher has observed that, in practice, such meetings are almost non-existent. It is yet to be established whether members of the school boards (and the public) are aware of this clause in the Education Act, 2010. It is not stipulated in Lesotho's education documents what other roles parents should play in the education of their children- apart from also paying school fees. Thus, there is no document to guide parents (individually or as groups) on how they should interact with teachers every day for the betterment of education.

This article reports on the findings of a study in which parents of learners in three inclusive secondary schools within the Maseru District of Lesotho were assessed for their knowledge and views about PIE, and their contributions to the education of their children. The objectives of this study were to:

(a) Determine the extent to which parents know about their roles in the education of their children.

(b) Explore the views of parents about PIE.

(c) Determine the extent to which parents played certain specific roles in the education of their children.

(d) Drawing from the findings of this study, as well as the literature - to propose strategies for improved and sustained PIE in (secondary) schools in Lesotho.

Parental roles in inclusive schools are not unique. Optimal parental involvement in any other educational setting is all that is required - even for inclusive schools. Past research in Lesotho shows that PIE is minimal. However, the focus has been mainly on teachers' views about the assistance they received from parents. In order to have a complete understanding of PIE in Lesotho, the researcher attempted to investigate this concept from the parents' point of view. The study findings could raise awareness among key stakeholders in Lesotho's education sector about the important roles that parents can (and should) play in the education of their children. The researcher also hoped this study would inspire the respondents to rethink their roles and contributions to the education of their children (and to improve upon this if necessary). Although the proposed strategies to improve and sustain PIE in (inclusive) schools in Lesotho were based on a sample of only three schools, it is hoped that the proposed strategies could also apply to other schools (even to schools outside of Lesotho) - although adaptations might be necessary. The theoretical framework and literature review that pertains to this study, are discussed next.

\section{Theoretical Framework and Literature Review}

Bourdieu's $(1985,1999)$ concept of cultural capital becomes important for this study. According to DiGiorgio (2009:181), cultural capital represents "... resources that people accumulate and exchange in order to maintain their positions of power within a field." Thus, cultural capital represents non-financial assets that individuals possess and which determine their status in their field. This includes external markers such as educational qualifications, skills, language and authority. Bourdieu (1985) maintains that cultural reproduction entails transfer of the various forms of capital from one generation to the next, and according to this author, education represents a key example of this process.

Drawing on the work of Bourdieu on cultural reproduction, Blasko (2003) maintains that it is the upper classes that have benefited the most from cultural assets. The author states that, although cultural assets have helped the upper classes to maintain their existing positions within their communities (their fields) - they can also provide a possible source for those occupying lower positions in the social hierarchy to support their children going forward. Thus, cultural capital can have a bigger impact on the status-attainment process of those from the lower classes. This implies that it is possible that upward-looking, uneducated parents, who realise the importance of education, will also motivate their children to work toward achieving high educational qualifications. In the current study, the people who fall in the category of the upper classes could be parents with a higher level of education (and 
probably better wealth). On the other hand, those within the lower classes, could be those with poor socioeconomic status and with education levels below secondary/high school.

Although several models for involving parents in education have been proposed, Epstein's (1995) model of overlapping spheres of influence (figure A), is considered in this article to be crucial in terms of linking together the activities of parents (family), teachers (school) and the communities in schools - while at the same time providing autonomy for those three parties in certain educational aspects. Thus, parents, teachers and the communities have individual roles, as well as shared roles in education. The researcher believes that each of these three spheres needs to be fully developed, as the larger the sphere and the more they overlap, the more the benefits there are for learners. Thus, each of these parties should be equipped with the necessary skills and resources to participate meaningfully in education as individuals, and to perform their shared roles optimally. Consequently, this article has focused on the parental sphere of influence - in order to fully understand it and ultimately to expand it by proposing some developmental strategies. As indicated earlier, past research in Lesotho has focused mainly on the understanding and development of the schools' (teachers') sphere of influence. So this article has attempted to bridge the gap by also considering the parental sphere. It is hoped that future research will look into the community's sphere, for the purpose of ultimately producing an effective and sustainable PIE in Lesotho's inclusive(secondary) schools.

\section{Figure A}

$\mathrm{L}=$ Learner

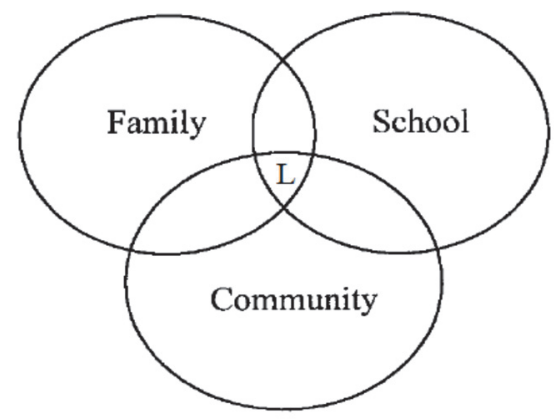

Figure A. The overlapping spheres of influence related to parental involvement (Adapted from Epstein, 1997)

As Lemmer (2007) has pointed out, in many African countries (Lesotho included), one of the strongest trends in education reform has been to give parents an increased role in governing schools. As the author maintains, this does not provide opportunities for parents to be actively involved in teaching and learning in schools - which deprives learners of much needed improvements in academic achievement.

PIE is a complex phenomenon that is defined differently in different contexts. In this article, PIE will refer to parents' fulfilment of their obligations and responsibilities in the education of their children - such as attending school meetings; communicating with schools (teachers) about a learner's educational progress; being actively involved in parent-teacher associations; helping children with academic activities at home and in school (e.g. through volunteering); attending school-initiated functions; having high aspirations, attitudes and beliefs about their children's education; offering their expertise to schools; creating a conducive learning environment at home; engaging in learning activities at home with their children; and encouraging, guiding, monitoring and discussing school subjects and experiences with their children (Makgopa \& Mokhele, 2013). It is argued that parents should act as the steering wheel on the vehicle of learning, providing their children with guidance and information along the educational journey - in order for their children to stay focused and not to be distracted from reaching their educational potential (Olatoye \& Agbatogun, 2009; Learning Liftoff, 2017).

PIE is considered to be crucial for quality education, mainly at lower levels (secondary education and below). Quality, in this sense, refers to nurturing holistically all the aspects of human life - inter alia academic, social, and psychological. In other words, it could be extremely challenging to achieve the goals envisaged for education if parents are not actively involved. According to Ntekane (2018), PIE helps parents to see the value of education. Indeed, Porter (2002) argues that parents have the right to be involved and to have their wishes respected with regard to their children's education. 
There are many ways in which parents can be involved in their children's education. These include reading books together, listening to them reading, helping them with assignments, exploring nature together, ensuring that they are engaged and challenged in their educational environment, following up on their children's academic performance, communicating with teachers about their children's education, and by availing themselves during school-parent meetings and workshops. They could also provide their children with other learning alternatives such as online learning, and exploring other learning alternatives such as private lessons/tutoring outside school time. Furthermore, parents could become part of school boards, and participate in the development and evaluation of their children's individualised education plans (IEPs). They should also be involved in children's sports activities, as this might improve a child's achievements in extra-curricular activities, while also serving as motivation for the child (Clinton \& Hattie, 2013; Hornby \& Lafaele, 2011; Liftoff, 2017).

Even parents from the lower classes (thus, with lower levels of education and those with lower socio-economic status) have roles to play in the education of their children. Apart from offering support and motivation to their children, they might engage in volunteering services in the schools - such as improving schools' infrastructure, ensuring cleanliness and helping with discipline. They might also discuss with teachers (and also with the children themselves) other ways in which they can make contributions to their children's education. A Ghanaian study by Chowa, Masa and Tucker (2013) found that even parents from lower classes were highly involved in the education of their children. Such parents ensured that their children attended school regularly and that they completed assignments. Moreover, they attended school meetings regularly, checked their children's books, and discussed their children's work with teachers. According to Chowa et al. (2013), less educated parents were more involved in their children's education - probably because they wanted their children to be better educated than they were. This confirms Blasko's (2003) idea of the cultural assets of the higher classes (high educational qualifications in this case) as motivating the lower classes (uneducated parents) to work hard, in order to ensure that their children also attain them.

Ntekane (2018) advocates the use of effective strategies to encourage parents to be actively involved in the education of their children. The author proposes traditional as well as non-traditional methods of encouraging PIE. Traditional methods include publicising parent-school meetings through community chiefs, church and funeral service announcements, and using flyers and sending invitation letters via learners. Non-traditional methods include the use of television, phone calls and sending emails. There are software platforms and mobile applications that schools can use to interact with parents and to inform them, inter alia, about a child's performance (even on a daily basis), assignments and class resources, and parents' meetings/workshops. Ntekane (2018) has noted that the use of only traditional methods could tend to be ineffective in cases where certain parents rely on nontraditional methods.

Linguistic cultural capital is also crucial for the success of PIE. Russel (2005) believes that open and constant communication is essential for effective collaboration between schools, parents and the wider community, and can also help foster a shared sense of purpose among all stakeholders. Thus, communication barriers may deter parents from participating in school affairs. English is a second language in Lesotho, and therefore some parents may not be conversant in it. It is therefore important that all information provided be in written form, in both Sesotho and English.

According to Msila (2012), students whose parents monitor and regulate their activities, provide emotional support, encourage independent decision-making and are generally more involved in their schooling - are less likely to drop out of school. Similar sentiments reflect in Eizadirad's (2016) narrative about his experiences while schooling in a foreign country. Eizadirad's makes it explicit that parental support is crucial for a child's success in learning: "[c]ultural differences and language barriers made school very difficult for me to the extent that I felt I did not belong" (Eizadirad, 2016:8). The author indicates that even though schooling was an uphill journey for him, the support he received from his parents, teachers and mentors inspired him to not give up. He further states that “... it is tragic that many students do not get the same opportunity that I was offered; an opportunity to progress themselves to their full potential because they are not guided in a supportive [manner]" (Eizadirad, 2016: 8).

So many benefits of PIE have been documented. Some benefits of PIE have already been highlighted. Others include enabling partnerships between teachers, parents and the community in order to understand and cope with an individual child's uniqueness. PIE is also considered to contribute to children's positive attitudes towards learning. Liftoff (2017: 1-2) summarises the benefits of PIE as follows:

- Parents and children enjoy a deeper interaction.

- Children who received schooling at home tend to do better on standardised tests.

- Children show improved self-esteem and self-worth, improved confidence, and better behaviour. 
- Children complete homework more easily and consistently.

- Children receive better grades on tests and attendance.

- Parents are more aware of what their children are learning and can pinpoint key areas or subjects that the children may need additional help with.

Most studies from the developed countries show successful PIE, while those from developing and under-developed countries have reported mixed results. A Namibian study by Erlendsdóttir (2010) shows that both privileged and underprivileged parents of learners in a school that catered for children from different socio-economic backgrounds were highly involved in their children's education at school and at home. According to Erlendsdóttir, this could be due to parents having high expectations for their children. In contrast, the South Africa studies by Engelbrecht, Forlin, Eloff and Swart (2001), Mahlo (2011), Maluleke (2014), Manilal (2014), Msila (2012) and Nojaja (2009), reported minimal PIE for inclusive schools - especially in the disadvantaged, rural schools. In Ghana, Pryor and Ampiah (2003) reported that most parents in the town of Akurase were indifferent to or uninterested in the education of their children - as to them education was unproductive in terms of their children's future careers as farmers. This Ghanaian study revealed that when there is a mis-match between cultural capital (educational qualifications) and symbolic capital (prestige, honour, and the right to be heard), education is compromised.

In 2011, Sottie found that single parents in Ghana were less involved in their children's education compared with married couples. The author ascribed this to single parents' impoverishment. Still in Ghana, Donkor, Issaka and Asante (2013) conducted a study in a school in a community with a high illiteracy rate and low-income, and showed that students received little support from their parents. Similar findings were made by Lemmer and Van Wyk (2004) in South Africa, where it was found that parents with limited or no education had the will to help their children - but were constrained because they were (wrongly) convinced that they were incapacitated by their limited school education to help their children with their learning. While acknowledging the significant impact of poverty on Black parents' efforts to support their children's education, Ndlazi (1999: 66) added that "... lack of parental involvement has been dominant among black parents [also] because of their illiteracy and ignorance." Scholars (e.g. Miles, 2005; Stubbs, 2002) have also linked disability with poverty, indicating that PIE is most likely to be even lower in inclusive schools. According to these authors, families that are struggling with disability are also poor, because of several factors or challenges - including negative attitudes, problems with mobility, earning power, and child-care problems.

In Nigeria, it appeared that parents who sent their children to private schools were more involved with them than those whose children were sent to public schools (Olatoye \& Agbatogun, 2009). The same study revealed an element of gender bias, whereby parents were more involved in their sons' education than in the education of their daughters'. In Lesotho, Ralejoe (2016) showed that teachers were not completely satisfied with the level of support that they received from parents of learners with disabilities.

Based on the benefits of PIE discussed above, and the reports that it is insufficient mostly in inclusive schools, the author investigated this concept from a parents' point of view to devise means and strategies to improve and sustain it. Ralejoe (2016) indicated that inclusive schools in Lesotho are found mainly within the Maseru District, and that this has forced most learners with disabilities to leave their homes to attend school. Some of them live with relatives, some rented accommodation, while others live in school hostels (boarding accommodation). Lesotho has a high rate of unemployment (23.6\% in 2018: Damane \& Sekantsi, 2018) and most parents work in the fabric factories in Maseru and Maputsoe (Leribe District).

\section{Methodology}

For this study, the quantitative approach was selected for its strength in enabling researchers to explore trends and to explain the relationships among different variables (Creswell, 2008). Quantitative research depends on quantitative data such as a survey questionnaire or focuses on testing a hypothesis. The study was exploratory in approach. Here, a survey questionnaire was used as a research instrument, in order to investigate parents' knowledge and views about PIE. The survey questionnaire has helped the researcher to reach as many respondents as possible and to generalise the research findings to a representative population (Gall, Gall \& Borg, 2003). Due to fewer inclusive schools in Lesotho, three inclusive schools were purposefully selected in the Maseru District. They were all situated around the Maseru city. The inclusive schools in Lesotho are partially inclusive (i.e. each can accommodate only a few types of disabilities).

Data were generated through responding to a 5-point Likert scale questionnaire (strongly agree, agree, not sure, disagree, and strongly disagree). The questionnaire comprised 17 response items. The researcher distributed 700 questionnaires to parents (through their children). After filling in the questionnaires, parents (through their children) 
were to return them to principals' offices - and the researcher collected them from there. Of 521 collections, 475 were fully completed and were used for this study. Then, the data were analysed using SPSS software.

\section{Results}

\subsection{Biographical Information}

The study sample was made up of 147 males (30.9\%) and 328 females (69.1\%). Most research participants (56.6\%) had high school education, while $21.5 \%$ had below high school education and $21.9 \%$ had tertiary education.

Table 1.1 Biographical information of the study sample

\begin{tabular}{llcc}
\hline & Category & Frequency & Percentage \\
\hline \multirow{2}{*}{ Gender } & Male & 147 & $30.9 \%$ \\
& Female & 328 & $69.1 \%$ \\
\hline \multirow{3}{*}{ Education } & Below Secondary/High school & 102 & $21.5 \%$ \\
& Secondary/High school & 269 & $56.6 \%$ \\
& Tertiary & 104 & $21.9 \%$ \\
\hline
\end{tabular}

\subsection{Exploratory Factor Analysis of the Understanding of Parental Involvement in the Teaching of their Children}

The construct of understanding parental involvement in the teaching of a child is made up of 11 questionnaire items listed in Table 1.2A (below). The exploratory factor analysis results in Table 1.2A show that the 11 items can be subdivided into three sub-constructs or latent factors, with the suggested names: Parental teaching support (Questions 1, 6, 11, 13, 14 and 17); Parental emotional support (questions 8, 9 and 16); and School management participation (question 4).

Three latent variables were created, using principal components, to represent the three constructs for further analysis. The latent factors are then compared to evaluate the effects of gender and education on parents' levels of understanding of parental involvement in the teaching of their children.

Table 1.2A Exploratory factor analysis of parental involvement

\begin{tabular}{|c|c|c|c|}
\hline \multirow{2}{*}{ Parental Involvement items } & \multicolumn{3}{|c|}{ Latent Factors } \\
\hline & Factor 1 & Factor 2 & Factor 3 \\
\hline $\begin{array}{l}\text { Q1. It is important for parents to help teachers in the education } \\
\text { of their child? }\end{array}$ & 0.494 & & \\
\hline $\begin{array}{l}\text { Q6. Parental involvement in the education of their children is } \\
\text { not the idea of lazy teachers. }\end{array}$ & 0.439 & & \\
\hline $\begin{array}{l}\text { Q11. Parents should help their children with subject contents, } \\
\text { even though they are not trained to do so. }\end{array}$ & 0.478 & & \\
\hline $\begin{array}{l}\text { Q13. Parents who help their children with school work do not } \\
\text { promote laziness in teachers. }\end{array}$ & 0.640 & & \\
\hline $\begin{array}{l}\text { Q14. Educational discussions between parents and their } \\
\text { children improve their relationships. }\end{array}$ & 0.508 & & \\
\hline $\begin{array}{l}\text { Q17. Children whose parents help with school work often } \\
\text { perform well academically. }\end{array}$ & 0.628 & & \\
\hline $\begin{array}{l}\text { Q12. Parents should not interact with teachers -only when } \\
\text { their children are experiencing a learning-related crisis. }\end{array}$ & -0.404 & & \\
\hline $\begin{array}{l}\text { Q8. A child's lack of progress in school could be an indication } \\
\text { of weakness in the collaboration between child and parent. }\end{array}$ & & 0.472 & \\
\hline Q9. Parents should provide emotional support to their children & & 0.397 & \\
\hline
\end{tabular}


when they have performed badly in their school work.

Q16. The schools' curricula should clearly stipulate parental roles in education.

Q4. I can happily represent parents on the school board.

0.666

\begin{tabular}{cccc}
\hline Suggested factor name & $\begin{array}{c}\text { Parental } \\
\text { teaching } \\
\text { support }\end{array}$ & $\begin{array}{c}\text { Parental } \\
\text { emotional } \\
\text { support }\end{array}$ & $\begin{array}{c}\text { School management } \\
\text { participation }\end{array}$ \\
\hline
\end{tabular}

Table 1.2B (below) shows the descriptive statistics of the first latent factor - parental teaching support.

Table 1.2B Descriptive statistics of parental teaching support

\begin{tabular}{|c|c|c|c|c|c|c|}
\hline Parental teaching support & $\begin{array}{l}\text { Disagree/ } \\
\text { Strongly } \\
\text { Disagree }\end{array}$ & Neutral & $\begin{array}{l}\text { Agree/ } \\
\text { Strongly } \\
\text { agree }\end{array}$ & Mean & Std Dev & \begin{tabular}{|l} 
Latent \\
Factor \\
Coefficient
\end{tabular} \\
\hline Q1. It is important for parents to help Count & 17 & 5 & 453 & \multirow{2}{*}{4.61} & \multirow{2}{*}{0.76} & \multirow{2}{*}{0.532} \\
\hline teachers in the education of their child. $\%$ & $3.6 \%$ & $1.1 \%$ & $95.4 \%$ & & & \\
\hline Q6. Parental involvement in the Count & 111 & 46 & 318 & \multirow[b]{2}{*}{3.72} & \multirow[b]{2}{*}{1.43} & \multirow[b]{2}{*}{0.412} \\
\hline $\begin{array}{l}\text { education of their children is not the idea } \% \\
\text { of lazy teachers. }\end{array}$ & $23.4 \%$ & $9.7 \%$ & $66.9 \%$ & & & \\
\hline Q11. Parents should help their children Count & 84 & 48 & 343 & \multirow[b]{2}{*}{3.85} & \multirow[b]{2}{*}{1.26} & \multirow[b]{2}{*}{0.501} \\
\hline $\begin{array}{l}\text { with subject contents - even though they } \\
\text { are not trained to do so. }\end{array}$ & $17.7 \%$ & $10.1 \%$ & $72.2 \%$ & & & \\
\hline Q13. Parents who help their children Count & 70 & 40 & 365 & \multirow[b]{2}{*}{3.98} & \multirow[b]{2}{*}{1.26} & \multirow[b]{2}{*}{0.680} \\
\hline $\begin{array}{l}\text { with school work do not promote } \\
\text { laziness in teachers. }\end{array}$ & $14.7 \%$ & $8.4 \%$ & $76.8 \%$ & & & \\
\hline Q14. Educational discussions between Count & 30 & 23 & 422 & \multirow[b]{2}{*}{4.38} & \multirow[b]{2}{*}{0.92} & \multirow[b]{2}{*}{0.518} \\
\hline $\begin{array}{l}\text { parents and their children improve their } \% \\
\text { relationships. }\end{array}$ & $6.3 \%$ & $4.8 \%$ & $88.8 \%$ & & & \\
\hline Q17. Children whose parents help with Count & 31 & 38 & 406 & \multirow[b]{2}{*}{4.29} & \multirow[b]{2}{*}{0.97} & \multirow[b]{2}{*}{0.655} \\
\hline $\begin{array}{l}\text { school work often perform well } \\
\text { academically. }\end{array}$ & $6.5 \%$ & $8.0 \%$ & $85.5 \%$ & & & \\
\hline
\end{tabular}

The results in table 1.2B demonstrate that most parents (95.4\%) understand that it is their responsibility to support teachers in the teaching of their children. In the same vein, $76.8 \%$ understand that their support to teachers cannot promote laziness in teachers, and $66.9 \%$ cannot trace this concept as emanating from lazy teachers. Moreover, $72.2 \%$ believe that parents have a role to play in their children's understanding of subject matter, and most of them $(85.5 \%)$ also believe that parental support to teachers improves the academic performance of their children. Also, most parents (88.8\%) think that their support to teachers can improve a bond between parents and their children. The next table (table 1.2C), describes the statistics of parental emotional support.

Table 1.2C Descriptive statistics of parental emotional support

\begin{tabular}{|c|c|c|c|c|c|c|}
\hline Parental emotional support & $\begin{array}{l}\text { Disagree/ } \\
\text { Strongly } \\
\text { Disagree }\end{array}$ & Neutral & $\begin{array}{l}\text { Agree/ } \\
\text { Strongly } \\
\text { agree }\end{array}$ & Mean & $\begin{array}{l}\text { Std } \\
\text { Dev }\end{array}$ & $\begin{array}{l}\text { Latent } \\
\text { Factor } \\
\text { Coefficient }\end{array}$ \\
\hline \multirow{2}{*}{\begin{tabular}{l|l} 
Q8. A child's lack of progress in school could & Count \\
be an indication of weakness in the & $\begin{array}{l}\text { of } \\
\text { collaboration between a child and a parent. }\end{array}$
\end{tabular}} & 122 & 113 & 240 & \multirow[b]{2}{*}{3.30} & \multirow[b]{2}{*}{1.21} & \multirow[b]{2}{*}{0.651} \\
\hline & $25.7 \%$ & $23.8 \%$ & $50.5 \%$ & & & \\
\hline \multirow{2}{*}{\begin{tabular}{l|l} 
Q9. Parents should provide emotional support & Count \\
to their children when they have performed & $\%$
\end{tabular}} & 74 & 19 & 382 & \multirow{2}{*}{4.02} & \multirow{2}{*}{1.20} & \multirow{2}{*}{0.497} \\
\hline & $15.6 \%$ & $4.0 \%$ & $80.4 \%$ & & & \\
\hline
\end{tabular}




\begin{tabular}{|l|l|l|l|l|l|l|l|}
\hline badly in their school work. & & & & & & & \\
\hline \multirow{2}{*}{$\begin{array}{l}\text { Q16. The schools' curricula should clearly } \\
\text { stipulate parental roles in education. }\end{array}$} & 62 & 116 & 297 & 3.73 & 1.05 & 0.647 \\
\hline
\end{tabular}

From the results in table $1.2 \mathrm{C}$ (above), it can be seen that most parents $(80.4 \%)$ value emotional support to their children - especially when they seem to be struggling with their school work. On the other hand, just over half of the respondents $(50.5 \%)$ could link a poor performance in school work to weakness in the parent-child collaboration. Furthermore, a considerable number of parents $(62.5 \%)$ believed that parents were unaware of the roles that they should play in the education of their children, and therefore, they believed that it would be helpful to them if such roles could be stipulated in the schools' curricula. The descriptive statistics of the third latent factor - parental school management participation - is presented in table 1.2D (below).

Table 1.2D Descriptive statistics of parental school management participation

\begin{tabular}{lcc}
\hline School Management participation/support & & \\
\hline Q4. I can happily represent parents on the school board. & 112 & $23.6 \%$ \\
Disagree/Strongly disagree & 86 & $18.1 \%$ \\
Not sure & 277 & $58.3 \%$ \\
Agree/ Strongly agree
\end{tabular}

From table 1.2D, it can be noted that a considerable number of parents (58.3) were happy to partake in the management of the schools that had enrolled their children - by representing other parents on the school board (school management committee).

\subsection{Exploratory Factor Analysis and Descriptive Statistics of Parental Contribution to the Teaching of Their Children}

Principal components-based exploratory factor analysis of the construct of parental contribution yielded two subconstructs (latent factors) that are presented in Table 1.3A (below).

Table 1.3A Exploratory factor analysis of parental contribution

\begin{tabular}{|c|c|c|}
\hline \multirow{2}{*}{ Parental Involvement items } & \multicolumn{2}{|c|}{ Latent Factors } \\
\hline & Factor 1 & Factor 2 \\
\hline Q2. I always attend school-parent meetings and workshops. & 0.617 & \\
\hline $\begin{array}{l}\text { Q3. Voluntarily, I sometimes visit/call/email or use social media } \\
\text { communication to discuss my child's progress with his/her teachers. }\end{array}$ & 0.623 & \\
\hline $\begin{array}{l}\text { Q7. I often ensure that my child has correctly done his/her homework, } \\
\text { and where I also cannot help, I often find someone else to help } \\
\text { him/her. }\end{array}$ & 0.613 & \\
\hline $\begin{array}{l}\text { Q15. I have provided my child with supplementary learning } \\
\text { materials. }\end{array}$ & 0.536 & \\
\hline $\begin{array}{l}\text { Q5. As parent, I always pay for remedial classes when my child } \\
\text { experiences difficulties learning in school. }\end{array}$ & & 0.713 \\
\hline $\begin{array}{l}\text { Q10. Despite my work-load, I always attend school-parent meetings } \\
\text { or workshops. }\end{array}$ & & 0.626 \\
\hline Suggested factor name & $\begin{array}{c}\text { Child } \\
\text { monitoring }\end{array}$ & $\begin{array}{c}\text { School programme's } \\
\text { participation }\end{array}$ \\
\hline
\end{tabular}

Two latent variables will be created, using principal components, to represent the three constructs for further analysis. The suggested names for these sub-constructs of parental contribution to the teaching of their children are: child monitoring (questions 2, 3, 7 and 15), and parent's participations in school programmes (questions 5 and $10)$. 
The results in Table 3.3B (below) show that most parents (85.7\%) attend school-parent meetings and workshops, while fewer parents $(38.3 \%$ ) voluntarily communicate with teachers about their children's progress in school. Most parents $(83.4 \%)$ also help their children with homework, and 70.5\% supply their children with supplementary learning material.

Table 1.3B Descriptive statistics of child monitoring

\begin{tabular}{|c|c|c|c|c|c|c|c|}
\hline \multicolumn{2}{|l|}{ Child monitoring } & $\begin{array}{l}\text { Disagree/ } \\
\text { Strongly } \\
\text { Disagree }\end{array}$ & Neutral & $\begin{array}{l}\text { Agree/ } \\
\text { Strongly } \\
\text { agree }\end{array}$ & Mean & $\begin{array}{l}\text { Std } \\
\text { Dev }\end{array}$ & $\begin{array}{c}\text { Latent Factor } \\
\text { Coefficient }\end{array}$ \\
\hline Q2. I always attend school-parent meetings & Count & 37 & 31 & 407 & \multirow{2}{*}{4.18} & \multirow{2}{*}{0.93} & \multirow{2}{*}{0.637} \\
\hline and workshops. & $\%$ & $7.8 \%$ & $6.5 \%$ & $85.7 \%$ & & & \\
\hline $\begin{array}{lll}\text { Q3. } & \text { Voluntarily, } & \text { I }\end{array}$ & Count & 243 & 50 & 182 & \multirow[b]{2}{*}{2.86} & \multirow[b]{2}{*}{1.27} & \multirow[b]{2}{*}{0.630} \\
\hline $\begin{array}{l}\text { visit/call/email or use social media } \\
\text { communication to discuss my child's } \\
\text { progress with his/her teachers. }\end{array}$ & $\%$ & $51.2 \%$ & $10.5 \%$ & $38.3 \%$ & & & \\
\hline Q7. I often ensure that my child has & Count & 54 & 25 & 396 & \multirow[b]{2}{*}{4.14} & \multirow[b]{2}{*}{1.05} & \multirow[b]{2}{*}{0.635} \\
\hline $\begin{array}{l}\text { correctly done his/her homework, and } \\
\text { where I also cannot help, I often find } \\
\text { someone else to help him/her. }\end{array}$ & $\%$ & $11.4 \%$ & $5.3 \%$ & $83.4 \%$ & & & \\
\hline Q15. I have provided my child with & Count & 78 & 62 & 335 & \multirow{2}{*}{3.80} & \multirow{2}{*}{1.09} & \multirow{2}{*}{0.618} \\
\hline supplementary learning materials. & $\%$ & $16.4 \%$ & $13.1 \%$ & $70.5 \%$ & & & \\
\hline
\end{tabular}

The results in Table 1.3C (below) suggest that very few parents (29.1\%) attend school-parent meetings or workshops, but they are willing to pay for remedial classes when their children experience difficulties in learning at school $(80.0 \%)$.

Table 1.3C Descriptive statistics of school programme's participation

\begin{tabular}{|c|c|c|c|c|c|c|c|}
\hline \multicolumn{2}{|l|}{ School programme's participation } & $\begin{array}{l}\text { Disagree/ } \\
\text { Strongly } \\
\text { Disagree }\end{array}$ & Neutral & $\begin{array}{l}\text { Agree/ } \\
\text { Strongly } \\
\text { agree }\end{array}$ & Mean & $\begin{array}{l}\text { Std } \\
\text { Dev }\end{array}$ & $\begin{array}{l}\text { Latent Factor } \\
\text { Coefficient }\end{array}$ \\
\hline Q5. As parent, I always pay for remedial & Count & 66 & 29 & 380 & \multirow[b]{2}{*}{4.09} & \multirow[b]{2}{*}{1.16} & \multirow[b]{2}{*}{0.710} \\
\hline $\begin{array}{l}\text { classes when my child experiences } \\
\text { difficulties learning in school. }\end{array}$ & $\%$ & $13.9 \%$ & $6.1 \%$ & $80.0 \%$ & & & \\
\hline \multirow{2}{*}{$\begin{array}{l}\text { Q10. Despite my work-load, I always } \\
\text { attend school-parent meetings or } \\
\text { workshops. }\end{array}$} & Count & 293 & 44 & 138 & \multirow[b]{2}{*}{2.54} & \multirow[b]{2}{*}{1.34} & \multirow[b]{2}{*}{0.710} \\
\hline & $\%$ & $61.7 \%$ & $9.3 \%$ & $29.1 \%$ & & & \\
\hline
\end{tabular}

\subsection{Analysis of the Effects of Parent's Gender and Education on Parental Involvement in the Education of their \\ Children}

This section analyses the dependence of the three constructs of parental involvement in the education of their children on gender and education using analysis of variance (ANOVA).

\subsection{Parental Teaching Support}

The results in Table 1.4A (below) show that gender has a significant effect on parental teaching support $(\mathrm{F}=6.133$, $\mathrm{df1}=1$, df2=469, p-value=0.014) - with female parents having a higher mean (4.263) than male parents (mean=4.099). This means that female parents render significantly higher levels of support to the teaching of their children than male parents. 
Table 1.4A Tests for the effects of parent's gender and education on parental teaching support

\begin{tabular}{|c|c|c|c|c|c|c|}
\hline \multicolumn{7}{|c|}{ Means of Parental Teaching Support } \\
\hline \multirow{2}{*}{ Education } & \multirow{2}{*}{$\mathrm{N}$} & \multicolumn{2}{|c|}{ Subsets } & \multicolumn{3}{|c|}{ ANOVA tests } \\
\hline & & 1 & 2 & $\mathrm{~F}$ & $\mathrm{df} 1, \mathrm{df} 2$ & p-value \\
\hline Gender & & & & & & \\
\hline Male & 147 & 4.099 & - & 6.133 & 1,469 & 0.014 \\
\hline Female & 328 & - & 4.263 & & & \\
\hline Education & & & & & & \\
\hline Below Secondary/High school & 102 & 4.059 & - & 6.899 & 2,469 & 0.001 \\
\hline Secondary/High school & 269 & - & 4.241 & & & \\
\hline Tertiary & 104 & - & 4.337 & & & \\
\hline Gender*Education & & - & - & 0.897 & 2,469 & 0.409 \\
\hline
\end{tabular}

The results also show that there are significant differences in the parental teaching support given by parents with below secondary or high school education, and those with high school or tertiary education $(\mathrm{F}=6.899$, df $1=2$, $\mathrm{df} 2=469$, p-value $=0.001$ ). However, there is no significant difference between parents with high school $($ mean $=4.241)$ and those with tertiary (mean=4.337) education.

The results also showed that there is no significant interaction between gender and education in their effect on parental teaching support $(\mathrm{F}=0.897, \mathrm{df} 1=2, \mathrm{df2}=469$, $\mathrm{p}$-value $=0.409)$.

4.6 Parental Emotional Support

The results in Table 1.4B (below) show that neither gender nor education nor the interaction between the two have significant effects on parental emotional support (all p-values $>0.05$ ).

Table 1.4B Tests for the effects of parent's gender and education on parental emotional support

\begin{tabular}{|c|c|c|c|c|c|}
\hline \multicolumn{6}{|c|}{ Means of Parental Emotional Support } \\
\hline & \multirow{2}{*}{$\mathrm{N}$} & \multirow{2}{*}{\begin{tabular}{|l} 
Subsets \\
1
\end{tabular}} & \multicolumn{3}{|c|}{ ANOVA tests } \\
\hline & & & $\mathrm{F}$ & $\mathrm{df1}$, df2 & $\mathrm{p}$-value \\
\hline \multicolumn{6}{|l|}{ Gender } \\
\hline Male & 147 & 3.572 & 3.423 & 1,469 & 0.065 \\
\hline Female & 328 & 3.711 & & & \\
\hline \multicolumn{6}{|l|}{ Education } \\
\hline Below Secondary/High school & 102 & 3.654 & 0.305 & 2,469 & 0.737 \\
\hline Secondary/High school & 269 & 3.718 & & & \\
\hline Tertiary & 104 & 3.628 & & & \\
\hline Gender*Education & & - & 0.040 & 2,469 & 0.921 \\
\hline
\end{tabular}

\subsection{School Management Support}

The results in Table $1.4 \mathrm{C}$ (below) show that gender does not have a significant effect on parental school management support $(\mathrm{F}=0.669, \mathrm{df} 1=1, \mathrm{df} 2=469$, $\mathrm{p}$-value $=0.414)$. However, education has a significant effect on parental school management support $(\mathrm{F}=6.924, \mathrm{df} 1=1, \mathrm{df} 2=469$, $\mathrm{p}$-value $=0.001)$.

Table 1.4C Tests for the effects of parent's gender and education on parental school management support.

\begin{tabular}{|c|c|c|c|c|c|c|}
\hline \multicolumn{7}{|c|}{ Means of parental school management support } \\
\hline \multirow{2}{*}{ Education } & \multirow{2}{*}{$\mathrm{N}$} & \multicolumn{2}{|c|}{ Subsets } & \multicolumn{3}{|c|}{ ANOVA tests } \\
\hline & & 1 & 2 & $\mathrm{~F}$ & $\mathrm{df} 1, \mathrm{df} 2$ & $\mathrm{p}$-value \\
\hline \multicolumn{7}{|l|}{ Gender } \\
\hline Male & 147 & 3.540 & - & 0.669 & 1,469 & 0.414 \\
\hline Female & 328 & 3.432 & - & & & \\
\hline \multicolumn{7}{|l|}{$\overline{\text { Education }}$} \\
\hline Below Secondary/High school & 102 & 3.108 & - & 6.924 & 2,469 & 0.001 \\
\hline Secondary/High school & 269 & - & 3.520 & & & \\
\hline
\end{tabular}


Tertiary

104

Gender*Education

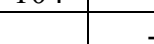

3.769

\begin{tabular}{l|lll}
- & 0.107 & 2,469 & 0.930
\end{tabular}

Parents with below secondary/high school education, with a mean of 3.108, have significantly lower levels of management support than those with high school (mean=3.520) or tertiary education (mean=3.769). Those with high school education do not differ significantly from those with tertiary education.

\subsection{Analysis of the Effects of Parent'S Gender and Education on Parental Contribution}

This section analyses the dependence of the two constructs of parental contribution to the education of their children on gender and education, using analysis of variance (ANOVA).

\subsection{Child Monitoring}

The results in Table 1.5A (below) show that education has a significant effect on parental child monitoring $(\mathrm{F}=8.296, \mathrm{df} 1=1, \mathrm{df} 2=469$, $\mathrm{p}$-value $<0.001)$, while gender has no significant effect $(\mathrm{F}=2.713, \mathrm{df} 1=1, \mathrm{df} 2=469$, $\mathrm{p}-$ value $=0.100$ ). Those with tertiary education tend to practice significantly higher levels of child monitoring (mean=3.993) than those with below high school education (mean=3.635) and those with high school education (mean=3.688).

Table 1.5A Tests for the effects of parent's gender and education on parental child monitoring

\begin{tabular}{|c|c|c|c|c|c|c|}
\hline \multicolumn{7}{|c|}{ Means of child monitoring } \\
\hline \multirow{2}{*}{ Education } & \multirow{2}{*}{$\mathrm{N}$} & \multicolumn{2}{|c|}{ Subsets } & \multicolumn{3}{|c|}{ ANOVA tests } \\
\hline & & 1 & 2 & $\mathrm{~F}$ & $\mathrm{df} 1, \mathrm{df} 2$ & $\mathrm{p}$-value \\
\hline Gender & & & & & & \\
\hline Male & 147 & 3.696 & - & 2.713 & 1,469 & 0.100 \\
\hline Female & 328 & 3.816 & - & & & \\
\hline Education & & & & & & \\
\hline Below Secondary/High school & 102 & 3.635 & - & 8.296 & 2,469 & $<0.001$ \\
\hline Secondary/High school & 269 & 3.688 & - & & & \\
\hline Tertiary & 104 & - & 3.993 & & & \\
\hline Gender*Education & & - & - & 0.691 & 2,469 & 0.502 \\
\hline
\end{tabular}

\subsection{School Programme's Participation}

The results in Table 1.5B (below) show that neither gender nor education nor the interaction between the two has any significant effect on parents' participation in school programmes (all p-values $>0.05$ ).

Table 1.5B Tests for the effects of parent's gender and education on parents' school programme's participation

\begin{tabular}{lc|c|ccc}
\hline \multicolumn{5}{c}{ Means of school programme's participation } \\
Education & $\mathrm{N}$ & $\begin{array}{c}\text { Subsets } \\
1\end{array}$ & $\mathrm{~F}$ & $\begin{array}{c}\text { ANOVA tests } \\
\text { df1, df2 }\end{array}$ & p-value \\
\hline Gender & 147 & 3.189 & 3.024 & 1,469 & 0.083 \\
Male & 328 & 3.356 & & & \\
Female & & & & & \\
Education & 102 & 3.294 & 0.651 & 2,469 & 0.522 \\
Below Secondary/High school & 269 & 3.336 & & & \\
Secondary/High school & 104 & 3.274 & & & \\
Tertiary & & - & 1.607 & 2,469 & 0.202 \\
\hline Gender*Education & & & & & \\
\hline
\end{tabular}

\section{Discussion}

Prior to discussing the findings of this study, it is important to highlight the possibility that some learners, instead of giving the questionnaires to their parents/guardians, could have filled them in themselves and then returned them to the principals' offices. It was impossible to trace such questionnaires and to discard them, given they were 
likely to provide an unreliable response. However, this potential threat in respect of the reliability of the data was minimised by taking a large sample.

The study findings indicate that most parents believed that it is their responsibility to support teachers as well as their children, in order for their children to succeed in education. For example, they thought that their children could learn better if they were emotionally supported (80.4\%), provided with supplementary learning materials (70.5\%), and also remedial classes (80.0\%). Indeed, these findings are encouraging, as Smit and Driessen (2005) state that parents are the primary educators of their children and therefore they should play an active role in the educational progress of their children. On the other hand, these results differ from those in Kaperu's (2004) Namibia-based study, where parents were found not to be quite sure of their roles in the education of their children.

Nonetheless, insufficient communication between most parents and teachers, as well as most parents' nonattendance of school events (e.g. school-parent meetings and workshops) could have proved detrimental to information transmission and sharing between parents and teachers - probably causing them to operate in isolation. According to Becker and Epstein (1982), parent-teacher meetings, workshops and conferences are the most typical form of communication between home and school, and these provide an opportunity for parents and teachers to discuss students' progress and problems, and allow parents to inform teachers of family experiences that may support learning. A report on research findings by Fantuzzo, McWayne, Perry and Childs (2004), reveals that parental involvement in school activities, as well as direct communication with teachers and administrators, is associated with greater achievement in mathematics and reading. In figure A above (The overlapping spheres of influence related to parental involvement), it is shown that a learner is situated in the intersection between parental and school (teachers') spheres, and that this overlap indicates cooperation between parents and teachers. It was indicated that a learner benefits more when this overlap is bigger. When the two parties operate in isolation, however, the overlap is smaller, and it becomes easier for one party to blame the other when things do not go well. This explains Ralejoe's (2016) study findings that teachers in inclusive schools in Maseru were not satisfied with parental contributions in the education of their children with disabilities and/or special educational needs. In the current study, almost half of the respondents $(49.5 \%)$ associated a child's poor performance in school with a failure on the side of teachers - indicating that, sometimes, parents blame teachers for the poor performance of learners.

Most parents in this study (70.9\%) thought that their work commitments prevented them from participating in parent-school meetings, workshops and conferences. This study did not establish what percentage of respondents is working class and/or their types of job. However, by serving as a secondary schools' educator within the Maseru District for nearly 20 years, the researcher knows that most respondents in the current study are a working group (and most of them work in the textile factories). This causes them to leave their homes very early in the morning, even before their children can go to school - and they return home very late. Some employers (mostly in the textile factories) do not allow their employees to take time off. Thus, if parents do not attend work, they may not get paid or are paid a reduced salary. This, therefore, may discourage parents from attending school functions and events that are scheduled for working days. To make matters worse, Saturday is considered a working day in most textile factories. This means that parents have less time to devote to their children's education. In South Africa, Mbokodi and Singh (2011) and Nojaja (2009) found that poor parental attendance at school meetings was attributed to work commitments and concomitant time constraints. In her 2014 study in the Vhembe District (Limpopo, South Africa), Maluleke also revealed that when parents have very tight work schedules, they do not have time to support the education of their children. In addition to work-related commitments, parental non-attendance of schools' activities could be attributed to their cultural norms - propagating what they have learnt from their own parents while they were students. In South Africa, Mbokodi and Singh (2011) found that parents did not attend meetings because they did not know why they should, when their own parents did not do it.

In the current study, the ANOVA tests revealed that gender plays a significant role in parental teaching support, with female parents rendering significantly higher levels of support to the teaching of their children than males. In the introduction section the author highlighted the trends within the Basotho's traditional child nurturing strategies, whereby Basotho women were mostly entrusted with the nurturing of children, rather than their male counterparts. Basotho men only played a significant role during the initiation schooling of boys. Now that modern schooling has gained popularity over traditional schooling, the period for motherly care has probably extended until children have completed secondary school education. Indeed, Donkor et al. (2013) maintain that although traditional social relationships have often been partially transformed to fit the needs of modern life, they continue to endure.

Furthermore, ANOVA tests have exhibited significant differences in the parental support to teachers. Those with high school or tertiary education provided more support than those with below secondary or high school education. The same goes for parental support to the learning of their children, whereby parents with tertiary education tend to practise significantly higher levels of support than those with below high school education and those with high 
school education. Indeed, scholars (e.g. Donkor et al., 2013; Lemmer \& Van Wyk, 2004) have associated a higher level of parental education to more parental involvement in the education of their children. According to Finders and Lewis (1994), limited parental schooling impairs parental assistance with homework beyond primary school level. Thus, some parents think that their own lack of education precludes them from participating in their children's education. The results also showed that there was no significant interaction between gender and education in their effect on parental teaching support and parents' child support.

The ANOVA tests further revealed that neither gender nor education nor the interaction between the two had significant effects on parental emotional support to their children. Moreover, education (but not gender) had a significant effect on parental school management support - with the parents having high school or tertiary education better supporting the management of the schools than those with education levels below secondary education. The results have also revealed that poor parental participation in school programmes cannot only be attributed to parents' low levels of education or their gender. The ANOVA tests have shown that neither gender nor education nor the interaction between the two has any significant effect on parents' participation in school programmes (all p-values $>0.05$ ). In their responses to the question on the questionnaire, most parents have acknowledged that their poor socio-economic status prevented them from partaking in school activities and events.

Scholars warn against language barriers as potentially discouraging most parents from participating in school affairs. English is a second language in Lesotho (and a medium of instruction in Lesotho secondary schools), and therefore those parents who are not conversant in it could feel left out and intimidated when school meetings, workshops and conferences are conducted in English. Such parents could feel discouraged about attending future meetings. Perhaps future research is encouraged in order to determine potential language barriers in the communication between parents and teachers.

Furthermore, the chasm between teachers and parents could also have resulted from the learned helplessness from the parental side. If parents (wrongly) think that education is solely the responsibility of teachers, then this perception may be carried down to future generations and become part of the culture. Hanson (1991) cautions that although culture may be viewed as an asset, it may also prove to be a liability. Thus, culture may prevent adaptation to new circumstances, and hence it may become a liability in situations where adaptation is essential. Further inquiry is needed in order to look into this potential threat to parental involvement in education, with regard to inclusive schools.

\section{Conclusion}

This study has revealed that most parents understand the importance of PIE, but they are operating in isolation from the teachers - probably because of poor communication between the two groups (parents and teachers), and because of the (wrong) perception that PIE has to do with parents' education levels. Mothers were found to offer more support than fathers, with the higher the education qualifications, the better the support. The study has also established that most parents did not attend school meetings, while some did not even feel a need to help the management of the schools in the running of the schools. Most respondents felt that their tight work schedules prevented them from attending school activities.

\section{Recommendations}

Based on the findings of this study, it is essential to devise strategies to improve the culture of PIE in the schools under study (and in any other schools under similar circumstances). Consequently, this study recommends that efforts be made to improve and sustain PIE. An improvement is needed, for example, in parents' understanding of PIE and their roles in the education of their children, in their communication with teachers, and in their attendance of school activities and events. In order to achieve this, schools (in collaboration with all other stakeholders) should develop a policy on PIE. It is recommended that instead of the top-down approach, the bottom-up approach be followed, as through this approach parents (as well as teachers) will be empowered and they will feel the ownership of the policy. The policy should then focus on strategies to raise awareness about PIE, should guide parents (and all other stakeholders) on their roles in education at school and at home, and should guide educators on their roles in making PIE work.

The policy proposed in this study should provide for the formation of 'PIE support groups' in an attempt to improve the interaction between parents and teachers for the benefit of learners. This support group should consist of equal numbers of representatives from teachers and parents, as well as one representative from the local businesses, learners, church leaders, social workers, governmental, as well as non-governmental organisations or associations in the community that are willing to serve on the group. It is proposed that the representatives in the PIE support group be renewed annually (and re-appointments after at least one-year break be allowed), so that everyone will have a chance to take part in the group. This will empower and encourage everyone to feel ownership of the PIE 
support group and also its activities. The local chief and the local council representative are already included in the school board (school governing body) - to which this support group will be accountable. In order to cater for all parents, the policy should be written both in Sesotho and in English. Guided by the school policy on PIE, the PIE support group (inter alia) will perform the following functions:

- Devise strategies to improve communication between parents, teachers and other stakeholders. Amongst other things, communication between parents and teachers can be achieved through meetings, letters, phone calls, emails and social media tools (e.g. Facebook, Twitter). Letters written to parents should be both in Sesotho and English. Other modes of information transmission that can be exploited include the distribution of posters, the use of billboards, festivals, sporting events, radio and television presentations, conferences, workshops, round-table discussions, drama and debates. With proper planning and arrangements, radio and television show calls, as well as short message services (SMS) - could also be used to raise funds for the schools.

- Using the communication modes stated above, raise awareness about PIE. Awareness campaigns could also help to inform and sensitise parents about the important roles that they can play (and should play) in the education of their children. These could be done by the Ministry of Education and Training (MOET), as well as PIE support groups.

- Encouraging parents and teachers to communicate regularly, in order to establish how children are progressing at school.

- In consultation with parents, find suitable days, venues and times for schools to use for parents' meetings and encourage parents to attend such meetings.

- Visit and support parents at home so that they can discuss with them issues related to PIE, and also in order to identify those who experience social difficulties - as such could also hamper their support of their children. If professional help is needed, they should refer such cases to suitable professionals, such as teachers, councillors, and community rehabilitation personnel. The home visits are a good way of forming home-school relationships, because they allow teachers and parents to get closer and to work together in dealing with needs or difficulties that the learner may experience. However, the home visits should not only focus on identifying problematic areas. They should also seek positive areas that teachers, learners and parents can capitalise on in order to improve learning.

- Plan for and encourage parents to participate in volunteering activities such as partaking in the school boards, monitoring schools' tuck shops, planning and monitoring educational tours, helping with schools' cleanliness, debate clubs, subjects' clubs (such as mathematics clubs and science clubs), training learners in sports and cultural activities, and raising funds for the schools.

- Encourage parents to continue supporting the learning of their children through activities such as buying supplementary learning materials (including internet sources), and signing of homework to show that they have assisted their children and have checked that it was completed.

- Devise mini projects, by which learners can contribute to the development of the communities surrounding the schools. These could include helping the elderly to produce vegetables and also cleaning for them.

The PIE policy should provide for parents (and all other stakeholders) to partake in the development of schools' academic goals and standards, as well as individual learner's individualised education plans (IEPs). Scholars show that when creating a high-quality instructional environment is a shared goal, parents transform from being passive supporters to being active members of the educational community. Indeed, as maintained in this study, if teachers and parents (and all other stakeholders) work together harmoniously, children feel motivated and they do their best to learn in school.

However, caution is needed to avoid over-promoting PIE. It is possible that some educators may feel like parents are getting overly involved and thereby overstepping their limits. Thus, great circumspection is needed when improving PIE - so that all parties (teachers included) feel empowered. Lastly, patience and persistence are needed when promoting PIE, because the adoption of new social conventions usually takes time.

\section{References}

Becker, H. J., \& Epstein, J. L. (1982). Parent involvement: A survey of teacher practices. The Elementary School Journal, 83(2), 85-102. https://doi.org/10.1086/461297

Blasko, Z. (2003). Cultural reproduction or cultural mobility? Review of Sociology, 9(1), 5-26. https://doi.org/10.1556/RevSoc.9.2003.1.1

Bourdieu, P. (1985). The social space and the genesis of groups. Social Science Information, 24(2), 195-220. 
https://doi.org/10.1177/053901885024002001

Bourdieu, P. (1999). Scattered remarks. European Journal of Social Theory, 2(3), 334-340. https://doi.org/10.1177/13684319922224563

Chowa, G. A., Masa, R. D., \& Tucker, J. (2013). The effects of parental involvement on academic performance of Ghanaian youth: Testing measurement and relationships using structural equation modelling. Children and Youth Services Review, 35(12), 2020-2030. https://doi.org/10.1016/j.childyouth.2013.09.009

Covey, S. R. (1989). The 7 habits of highly effective people: Powerful lessons in personal change. New York: Simon and Schuster.

Creswell, J. W. (2008). Educational research: Planning, conducting and evaluating quantitative and qualitative research (3rd Ed.). Upper Saddle River, NJ: Pearson Education, Inc.

Damane, M., \& Sekantsi, L. P. (2018). The Sources of Unemployment in Lesotho. Modern Economy, 9, 937-965. https://doi.org/10.4236/me.2018.95060

DiGiorgio, C. (2009). Application of Bourdieuian theory to the inclusion of students with learning/physical challenges in multicultural school settings. International Journal of Inclusive Education, 13(2), 179-194. https://doi.org/10.1080/13603110701350622

Donkor, A. K., Issaka, C. A., \& Asante, J. (2013). Cultural practices and education in Ghana: the effects of traditional culture on parental involvement in education. Research on Humanities and Social Sciences, 3(7), 110-120.

Eizadirad, A. (2016). International Experience in a Non-Western Country, Teacher Habitus, and Level of Inclusion in the Classroom. International Journal of Teaching and Education, IV(1), 1-15. https://doi.org/10.20472/TE.2016.4.1.001

Engelbrecht, P., Forlin, C., Eloff, I., \& Swart, E. (2001). Developing a support programme for teachers involved with inclusion in South Africa. International Journal of Special Education, 16(1), 80-89.

Epstein, J. L. (1995). School/family/community partnerships. Caring for the children we share. Phi Delta Kappan, May: 701-712.

Epstein, J. L. (1997). A comprehensive framework for school, family and community partnerships. In J. L. Epstein, L. Coates, K. C. Salinas, \& B. S. Simon (Eds.), School, family, and partnerships: Your handbook for action. Thousand Oaks, California: Corwin Press.

Erlendsdottir, G. (2010). Effects of parental involvement in education. A case study in Namibia. Unpublished M. Ed. dissertation. Iceland, University of Iceland.

Fantuzzo, J., McWayne, C., Perry, M., \& Childs, S. (2004). Multiple dimensions of family involvement and their relations to behavioral and learning competencies for urban, low-income children. The School Psychology Review, 33(4), 467-480. https://doi.org/10.1080/02796015.2004.12086262

Finders, M., \& Lewis, C. (1994). Why some parents don't come to school. Educational Leadership, 51(8), 50-54.

Fullan, M. (1997). Broadening the concept of teacher leadership. In S. Caldwell (Ed.), Professional development in learning-centered schools. Oxford, OH: National Staff Development Council.

Gall, D., Gall, P., \& Borg, R. (2003). Educational Research - An Introduction. Library of Congress Cataloging-inPublication Data, The United States of America.

Hanson, E. (1991). Educational administration and organizational behavior. Boston: Allyn \& Bacon.

Kaperu, G. (2004). Parental involvement in the education of their children. The case of unisa institutional repository.

Learning Liftoff. (2017). Why a Parent's Role Is Essential to Student Success. Retrieved from https://www.learningliftoff.com/category/education/learning-challenges/

Lemmer, E. M. (2007). Parent involvement in teacher education in South Africa. International Journal about parents in Education, 1(0), 218-229.

Lemmer, E., \& van Wyk, N. (2004). Schools reaching out: comprehensive parent involvement in South African primary schools. Africa Education Review, 1(2), 259- 278. https://doi.org/10.1080/18146620408566284

Lesitsi, A. M. (1990). Seemahale. Southern Africa: Hodder and Stroughton Educational.

Lesotho Government Gazette - Extraordinary. (2010). No. 20. Education Act, 2010. Lesotho: Government Printing 
- published by the Authority of His Majesty the King.

Macfarlane, A. (2005). Inclusion and Mäori ecologies: An educultural approach. In D. Fraser, R. Moltzen \& K. Ryba (Eds.), Learners with special needs in Aotearoa New Zealand (3rd ed.). Melbourne: Thomson Dunmore Press.

Mahlo, F. D. (2011). Experiences of Learning Support Teachers in the Foundation Phase, with Reference to the Implementation of Inclusive Education in Gauteng. Doctor of education, Thesis. South Africa: University of South Africa.

Makgopa, M., \& Mokhele, M. (2013). Teachers' perceptions on parental involvement: a case study of two South African schools. Journal of Educational and Social Research, 3(3), 219-225.

Maluleke, S. G. (2014). Parental Involvement in their children's education in the Vhembe District - Limpopo. Med. Thesis. University of South Africa, South Africa.

Manilal, R. (2014). Parental involvement in education: A comparison between a privileged and underprivileged school. MEd. Thesis. University of KwaZulu-Natal, South Africa.

Mbokodi, S. M., \& Singh, P. (2011). Parental Partnerships in the Governance of Schools in the Black Townships of Port Elizabeth. Perspectives in Education, 29(4), 38-48.

McLoughlin, S. W., Campbell, K. C., Eagle, J. F., Howard, C. J, Johnson, S. E., Macintosh, C. L., Scrivner, C. M. \& Williams, A. Y. (2012). Student motivation: A home remedy. Kappa Delta Pi Record, 39(3), 122-125.

Miles, S. (2005). Inclusive Education, Key issues and debates: Mainstreaming Disability in Development - The example of Inclusive Education. UK: Save the Children.

Msila, V. (2012). Black Parental Involvement in South African Schools: Will Parents ever help in Enhancing Effective School Management? 2(2). Unisa. Pretoria

Naidoo, D. (2004). Linking the utilization of research findings to research in MST education. Paper presented at the $12^{\text {th }}$ Annual Conference of the Southern African Association for research in Mathematics, Science and Technology Education. University of Cape Town.

Ndlazi, S. M. (1999). An investigation of parental non-involvement in the governance of a Duncan Village school and its implications for the management of the school: A case study. Unpublished MEd. Thesis. Rhodes University: Grahams town.

Nghipondoka, E. A. S. (2001). The Implementation of inclusive education in Tsandi Constituency, Namibia. Med. dissertation. Bellville: University of Western Cape.

Nojaja, J. M. (2009). A model for parent involvement in disadvantaged South African schools. Unpublished Doctor of Philosophy thesis. North-West University, Vanderbijl.

Ntekane, A. (2018). Parental Involvement in Education. https://doi.org/10.13140/RG.2.2.36330.21440

Okeke, C. I. (2014). Effective home-school partnership: some strategies to help strengthen parental involvement. South African Journal of Education, 34(3), 1-9.

Olatoye, R. A. \& Agbatogun, A. O. (2009). Parental involvement as a correlate of pupils' achievement in mathematics and science in Ogun State, Nigeria. Educational Research and Review, 4(10), 457-464.

Porter, L. (2002). Educating young children with special needs. London: Sage.

Pryor, J., \& Ampiah, J. G. (2003). Understanding of education in an African village: The role of information and communication technologies. Report on DFID Research Project Ed2000-88. Retrieved from http://www.sussex.ac.uk/education/cheer/documents/umea-conference-jan-2014-understandings-ofeducation-in-an-african-village.pdf (Accessed 15/03/2015).

Ralejoe, M. C. (2016). The perceptions of Lesotho secondary schools' teachers about the inclusion of students with disabilities. Unpublished doctoral dissertation. University of South Africa, Pretoria, RSA.

Russell, F. (2005). Starting school: The importance of parents' expectations. Journal of Research in Special Educational Needs, 5(3), 118-126.

Smit, F., \& Driessen, G. (2005). Ethnic minority parents' and teachers' orientation on collaboration between home and school: Strategies and contexts. Aula Abierta, 86, 169-184.

Sottie, C. A. (2011). Stemming the tide: School dropout in Ghana. Saarbrücken: Lambert Academic Publishing.

Stubbs, S. (2002). Inclusive Education: Where there are few resources. Norway: Atlas Alliance. 


\section{Copyrights}

Copyright for this article is retained by the author(s), with first publication rights granted to the journal.

This is an open-access article distributed under the terms and conditions of the Creative Commons Attribution license (http://creativecommons.org/licenses/by/4.0/). 